\title{
Source apportionment of metal elements in a river by using an effective variance chemical mass balance model: a feasibility study
}

PEIYUAN HSIEH ( $\sim$ hpyuann@gmail.com )

National Taiwan University https://orcid.org/0000-0002-7843-8374

Chi-Chang Ho

National Taiwan University

Gen-Shuh Wang

National Taiwan University

Yuan-Jeng Hsu

Environmental Protection Administration

Di-Wen Wang

Environmental Protection Administration

Yu-Man Shang

National Taiwan University

Chang-Fu Wu

National Taiwan University https://orcid.org/0000-0003-2244-1934

\section{Research Article}

Keywords: river pollution, source profile, source apportionment, spatial variation

Posted Date: March 7th, 2022

DOI: https://doi.org/10.21203/rs.3.rs-1383438/v1

License: (9) This work is licensed under a Creative Commons Attribution 4.0 International License.

Read Full License 


\section{Source apportionment of metal elements in a river by using an}

2 effective variance chemical mass balance model: a feasibility study

3

4 Pei-Yuan Hsieh ${ }^{1, *}$, Chi-Chang Ho ${ }^{1, *}$, Gen-Shuh Wang ${ }^{1}$, Yuan-Cheng Hsu ${ }^{2}$, Di-Wen

$$
\text { Wang }^{2} \text {, Yu-Man Shang }{ }^{1} \text {, Chang-Fu Wu }{ }^{1, \dagger}
$$

$6 \quad{ }^{1}$ Institute of Environmental and Occupational Health Sciences, National Taiwan

7 University, Taipei, Taiwan

$8{ }^{2}$ Environmental Analysis Laboratory, Environmental Protection Administration,

9 Executive Yuan, Taoyuan, Taiwan

11 Abstract

12 This technical report aimed to determine the sources of water pollution in a major

13 river in northern Taiwan by using the characteristics of actual industrial wastewater

14 and the effective variance chemical mass balance (EV-CMB) model. River water

15 samples from 9 sampling sites and 14 profiles of potential sources were collected and

16 a total of 52 metal elements were analyzed. To monitor the levels of industrial

17 pollutants in the water samples, the metal index (MI) is used. The model results

\footnotetext{
* These authors contributed equally to this work.

+ Corresponding author at: National Taiwan University, Room 717, No.17, Xu-Zhou Rd., Taipei 100, Taiwan. E-mail address: changfu@ntu.edu.tw (Chang-Fu Wu). 
18 identified the major sources of river pollution and may suggest the existence of

19 unknown sources. This study demonstrates the feasibility of applying the receptor

20 model in the strategic investigation of river pollution and highlights the need for a

21 comprehensive source profile database.

22

23 Keywords: river pollution, source profile, source apportionment, spatial variation

25 Article Highlights

26 - Feasibility of applying EV-CMB to investigate pollution sources of river water is

27 demonstrated.

28 Industrial sources showed different contribution patterns in terms of the total

29 mass concentration and metal index.

30

- Conducing a comprehensive view of effluent regulations on semi-conductors and

31 bare printed circuit boards manufacturing is recommended. 


\section{Introduction}

33 River pollution has caused serious concerns due to its long-term influence on the

34 environment and human health. Rivers usually have complex compositions that include

35 materials such as metal pollutants (Akbal et al., 2011; Ismail et al., 2016; Kumar et al., 2019; Li et al., 2015; Shil and Singh, 2019; Simeonov et al., 2003; Vu, 2017). To reduce water pollution and its potential hazardous impact, identifying the sources of pollutants and estimating their contribution to river pollution are essential.

39 The heavy metal pollution of river water is usually coming from discharge of

40 industrial wastewater in modern city. In order to evaluate the risk level of metal

41 pollution in the river water, monitoring the metal elements is crucial (Abdo and El-

42 Nasharty, 2010; Fishar and Ali, 2005). A metal index (MI) with regard to maximum

43 allowable concentration (MAC) has been used to evaluate the water quality (Goher et

44 al., 2014; Tamasi and Cini, 2004). The MAC of each element is adapted to local 45 conditions and usually the MAC is set to protect human health and ecological 46 environment.

47 Multivariate statistical techniques, such as absolute principal component scores48 multivariate linear regression and positive matrix factorization, have been widely 49 applied for the source apportionment of environmental pollution (Jiang et al., 2019; 50 Kowalkowski et al., 2006; Li et al., 2015; Palma et al., 2010; Soonthornnonda and 
51 Christensen, 2008; Zanotti et al., 2019; Zhou et al., 2007). The factor profiles retrieved

52 from these methods are interpreted with reference to empirical evidence and by

53 conducting a comparison of databases. However, the retrieved profiles may represent

54 mixed profiles from more than one source. By contrast, effective-variance chemical

55 mass balance (EV-CMB) model uses actual source compositions to evaluate unknown

56 source contributions in aerial and aqueous environment (Antony Chen et al., 2010;

57 Chow et al., 2007; Soonthornnonda and Christensen, 2008; Watson et al., 1984). The

58 EV-CMB model is expected to provide superior results than other models for the

59 clarification of sources when major source profiles in the study areas are available.

60 However, there is no application of this receptor model to investigate the river pollution

61 because of the difficulty in obtaining authentic wastewater samples.

62 In this technical report, we demonstrate the utility of using the EV-CMB model for

63 quantitative source apportionment of river pollution by measuring actual source

64 compositions of various industrial effluents, identifying and quantifying the pollutants

65 in surface river water, and estimating the spatial variation of pollution influences from 66 industrial activities. 
71 City in northern Taiwan. The overall length and drainage area of Nankan River are

72 approximately $30.7 \mathrm{~km}$ and $214.6 \mathrm{~km}^{2}$, respectively. Two industrial parks (Fig. 1), one

73 downstream and one upstream, are located in the research area. Numerous industrial

74 effluents are discharged into Nankan River. The middle of the river is in a metropolitan area with a high population density and various industries. To investigate the pollution area where people focus on, the midstream to upstream section of the Nankan River is selected.

78 Five sampling sites (S1, S2, S3, S4 and S5, sequentially arranged from downstream to upstream) were selected at the main stream along the river (Fig. 1). To monitor the

80 effects of the pollution from the tributaries, three additional sites $\left(\mathrm{S} 1^{\mathrm{T}}, \mathrm{S} 5^{\mathrm{T} 1}\right.$ and $\left.\mathrm{S} 5^{\mathrm{T} 2}\right)$

81 were selected at the mouth of different tributaries. S6 was regarded as background

82 water in this targeted river section. These sites $(\mathrm{N}=9)$ were monitored to assess the

83 spatial variations of water pollution. Each sample was collected using the standard

84 sampling method (TEPA, 2004), supplemented with nitric acid, and stored in a

85 refrigerator at $4^{\circ} \mathrm{C}$. 
87

\subsection{Sampling of industrial effluents}

88

To estimate the influences of industrial activities on river pollution, multiple

89 industrial effluents discharged into the river were collected as source profiles for the

90

measurement of wastewater compositions. Nine potential sources representing different

91 industrial classification were identified according to the daily flow of sewage treatment

92 (i.e., 3,600-28,100 $\mathrm{m}^{3}$ per day), as displayed in Fig. 2. The selected industries included

93 wastewater treatment plants (WTP); optoelectronic materials and components

94 manufacturing $(\mathrm{OMCM})$; semi-conductors manufacturing (SCM); finishing of textiles

95 (FT); bare printed circuit boards (BPCB); textiles mills (TM) and metal surface

96 treatment (MST). Since the river could be polluted by untreated wastewater, four

97 manufacturing units (SCM-p, FT-Ap, BPCB-p, and TM-p, where "p" means process

98 water) were collected based on previous violation. The effluents and process water from

99 these industries were collected in accordance with the standard method (TEPA, 2019)

100 and preserved with nitric acid at $4^{\circ} \mathrm{C}$.

101

102

\subsection{Chemical analysis}

103

Surface-water samples and industrial effluents were analyzed to determine their

104 elemental compositions. Inductively coupled plasma-mass spectrometry was conducted 
106 (NIEA W313). A total of 52 metal elements were analyzed in this study (Table S1). The

107 method detection limits (MDL) of these elements ranged from $0.03 \mu \mathrm{g} \mathrm{L}^{-1}$ to $1.67 \mu \mathrm{g}$

$108 \mathrm{~L}^{-1}$.

109

110

\subsection{Source apportionment}

111 In EV-CMB model, the mass balance equation can be written as

$$
X_{i j}=\sum_{k=1}^{p} g_{i k} f_{k j}+e_{i j}
$$

112 where $X_{i j}$ is the jth species concentration measured in the ith sample, $g_{i k}$ is the

113 contribution of the kth source pollution in the ith sample, $\mathrm{p}$ is the number of source

114 pollution, $f_{k j}$ is the source profile defined by the jth species concentration in the

115 contribution of the kth source pollution and $e_{i j}$ is the residual. The model uses

116 known source profiles to evaluate the unknown source contributions estimated from

117 the optimal resolution of mass-balance equations between the measured and

118 calculated pollutant concentrations. The model operation strategies and parameters are

119 described as follows:

120 (1) Selection of pollution compositions:

$121 \mathrm{Al}$ and $\mathrm{Fe}$ are the common elements in the crust. A large amount of these crustal

122 elements are dissolved in the river. Thus they are not suitable tracers and were 
excluded from the following analysis. Pollution compositions with concentrations less than MDL in all of the surface-water and source samples (i.e., Ir, Ru, and Tm) were excluded in the modeling process as well. For the remaining 47 compositions with concentrations less than the method detection limit (MDL), half of the MDL value was set as the concentration.

(2) Setting uncertainties for surface-water samples and source profiles: samples was assumed as $20 \%$ of the total mass according to empirical practice. For measured compositions, the uncertainties were estimated by

$$
u_{i j}=\sqrt{\left(0.5 \times M D L_{i j}\right)^{2}+\left(0.1 \times X_{i j}\right)^{2}}
$$
when the concentration was higher than the DL. Otherwise, the uncertainties were set as 5/6 of the DL in accordance with previous studies (Polissar et al., 1998).

134 (3) Selection of significant sources and fitting species: The sample collected from the background site is one type of pollution source

136 (background river water, S6). In the beginning, all the source profiles were assumed to be potential sources of water pollution in the model. The sources with high T-values (i.e., T-value $\geq 2$ ) were retained in the model as the major pollutant sources, and the remaining sources were removed from the model sequentially until all the sources had T-values larger than 2. Then, if the model performance 
did not meet all the criteria [i.e., $\mathrm{R}$-square value $\left(\mathrm{R}^{2}\right) \geq 0.8$, chi-square value $\left(\chi^{2}\right)$ $\leq 4.0$, the percent of measured and calculated mass concentration (\%MASS) ranged from $80 \%$ to $120 \%$, and the degree of freedom $(\mathrm{DF}) \geq 5$ ], the pollution compositions were reselected to improve the model performance. Compositions residual and $U$ is the uncertainty) were removed individually, and the model was result of source apportionment.

\section{Results and discussion}

\subsection{Characteristics of the metal elements in surface water samples}

157 S1. The concentrations of common crustal elements, Al, Fe, and Sr, were over $100 \mu \mathrm{g}$

$158 \mathrm{~L}^{-1}$ in all nine sampling sites. The concentration of $\mathrm{W}$ was the highest at $\mathrm{S} 5^{\mathrm{T} 2}$ (an

159 upriver tributary) and gradually decreased from upstream to downstream. As indicated 
160 in Table S1, the concentrations of $\mathrm{Cu}$ and $\mathrm{Mn}$ were the highest at $\mathrm{S}^{\mathrm{T}}$ (another

161 tributary), which might be why $\mathrm{S} 1$, where the $\mathrm{S} 1^{\mathrm{T}}$ tributary merged into the

162 mainstream, had high concentrations of these two elements as well.

163

164

\subsection{Characteristics of the metal elements in wastewater}

165

The profiles of the nine samples of industrial wastewater and four process waters

166 are displayed in Fig. 2. The compositions of all the samples met the effluent standards

167 established by the Taiwan Environmental Protection Administration (TEPA, 2019). In

168 addition, the high population density in the area surrounding the targeted river section

169 necessitates a profile of domestic wastewater. The penetration rate of sewer

170 construction in the study area was approximately $15 \%$ in 2019 , which makes domestic

171 wastewater a potential source of pollution. To determine an accurate profile of the

172 domestic wastewater discharged into Nankan River, a sample of untreated domestic

173 wastewater was collected from a domestic sewage treatment plant.

174

1753.3 River pollution level: metal index

176 To monitor the levels of industrial pollutants in the water samples on the basis of

177 the concentrations of regulated elements, the metal index (MI) is used. The MI is 178 defined as 


$$
\mathrm{MI}=\sum_{i} \frac{C_{i}}{\left(M A C_{i}\right)}
$$

179 where $C_{i}$ is the concentration of a regulated element. Tabel 1 presents the TEPA180 enforced maximum acceptable concentrations (in surface water) of 11 elements (Ag, $181 \mathrm{As}, \mathrm{Cd}, \mathrm{Cu}, \mathrm{Cr}^{6+}, \mathrm{Hg}, \mathrm{Mn}, \mathrm{Ni}, \mathrm{Pb}, \mathrm{Se}$, and $\mathrm{Zn}$ ). Because of their chemical properties, $182 \mathrm{Cr}^{3+}$ and $\mathrm{Cr}^{6+}$ can convert back and forth. To avoid underestimating the concentration 183 of $\mathrm{Cr}^{6+}$, total chromium was measured and used to estimate the MI. The spatial variations in total mass concentration (i.e., the sum of the metal elements) and MI are presented in Fig. 3. The total mass concentration was high in the upriver area where the industrial park was located and gradually decreased with distance. However, the MI did not follow the same pattern. The highest MI was observed at $\mathrm{S} 1$ (8.9), which might have been influenced by the $\mathrm{S} 1^{\mathrm{T}}$ tributary, which had an $\mathrm{MI} \leq 14.3$. In terms of the individual elements, Fig. 4 presents the unit MIs of the

19011 regulated metal elements. All the MIs of the regulated elements were less than one 191 at the background site (S6). The MIs of $\mathrm{Cu}$ and $\mathrm{Mn}$ increased from upstream to 192 downstream and both were larger than one at S1. However, the MI of Hg exhibited a 193 different pattern. The unit $\mathrm{MI}$ of $\mathrm{Hg}$ was the highest at $\mathrm{S}^{\mathrm{T} 2}$. After the tributary merged 194 into the mainstream, the unit MI of $\mathrm{Hg}$ decreased gradually with distance. 
198 (S1 to S5). The estimated percent mass concentrations (\%MASS) of the samples ranged

199 from $80.2 \%$ to $93.2 \%$. The model results fit the evaluation criteria $\left(\chi^{2} \leq 4, R^{2} \geq 0.8\right.$,

$80 \% \leq \% \mathrm{MASS} \leq 120 \%$, and $\mathrm{DF} \geq 5)$

201 The contributions of major industrial effluents along the mainstream are presented in

202 Fig. 5. SCM was the main contributor, and its contribution decreased gradually from

203 upstream to downstream. At S5, the contribution from $\mathrm{SCM}$ was $1658 \mu \mathrm{g} \mathrm{L}^{-1}$,

204 accounting for $78 \%$ of the total contribution (Fig. 6). Among the elemental

205 contributions of SCM, W had the highest proportion and was observed at all the

206 receptor sites (Fig. S1). This result corresponded to the profile of SCM, of which W

207 also comprised the greatest proportion (94.6\%, Fig. 2). Although W is not a regulated

208 element, studies have reported that W alloys may be carcinogenic (Van der Voet et al.,

209 2007; Wasel and Freeman, 2018; Witten et al., 2012).

210 OMCM and WTP-A were other major pollution sources, and their contributions

211 decreased with distance (Fig. 5). A small amount of background water was observed,

212 but its contribution diminished before reaching S1. By contrast, the contribution from

213 domestic wastewater increased from upstream to downstream because of the high

214 population density in the metropolitan area (around S1 and S2, Fig. 1).

215 All the pollution sources integrated at S1, which complicated the compositions of the 
216 samples. Domestic wastewater was the main source of pollution at S1 (21\%; Fig. 6),

217 followed by BPCB (19\%), SCM (18\%), and WTP-B (16\%). BPCB at S1 mainly came

218 from the nearby tributary $\left(\mathrm{S}^{\mathrm{T}}\right)$, and its contribution was up to $49 \%$ the $\mathrm{CMB}$ modeling

219 results (Fig. S2). WTP-B was another pollution source from S1 ${ }^{\mathrm{T}}(20 \%)$.

220 A comparison of the industrial effluent contributions at different receptor sites (Fig.

221 1) revealed that the pollutants at the sampling sites were affected by upstream industrial

222 effluents. For example, the WTP-B effluent entered the river through the upstream of

$223 \mathrm{~S} 1^{\mathrm{T}}$ (Fig. 1a), and its contribution was only observed at $\mathrm{S} 1^{\mathrm{T}}$ and the downstream of $\mathrm{S} 1$

224 (Fig. 6 and Fig. S2). This result made physical sense and indicated that the EV-CMB

225 model could effectively evaluate the influence of specific sources of pollution in the 226 river.

\subsection{MI apportionment}

To effectively manage and control the quality of river water, investigating the

230 source pollution of metal elements that are harmful to humans and the environment is

231 crucial. In this study, we analyzed MI apportionment among 11 elements.

232 Fig. 7 illustrates the contributions of industrial effluents to MI at the receptor

233 sites. SCM was the main contributor to MI upstream and accounted for $64 \%$ of the

234 total MI at S5. The contribution of SCM decreased with distance and was only $4 \%$ at 
235 S1. WTP-A was the second largest contributor to MI upstream (19\% at S5), but its

236 contribution diminished at S1. The contribution of MST emerged in the middle of the

237 river and was $12 \%$ at S3. Domestic wastewater flowed into the river through widely

238 distributed ditches. The largest contribution of domestic wastewater was observed at

239 S2 (35\%), which was close to the metropolitan area with a high population density.

$240 \mathrm{BPCB}$ was the main contributor to MI downstream (59\% at S1), followed by

241 domestic wastewater (15\%).

242 The main difference between the source contribution estimates based on total

243 mass concentration and the MI estimates is the influence of BPCB at S1 (19\% in Fig.

2446 and 59\% in Fig. 7). This is because $\mathrm{Cu}$ and $\mathrm{Mn}$ were the main elements contributing

245 to the MI at S1 (Fig. 4) and the elements comprising the two highest proportions of

246 the BPCB profile (Fig. 2). From the perspective of risk management, enhanced

247 regulations of BPCB discharge should be considered.

249 3.6 Study limitations

250 In this study, only a limited number of samples were collected to represent the major

251 sources of industrial effluents in the study area. Because effluents from different

252 factories in the same industry may exhibit similar pollution profiles, the EV-CMB

253 modeling results alone cannot be used to identify the exact sources of pollution. 
254 Nevertheless, this modeling approach can be used to narrow down the potential sources

255 to inform further investigation.

256

257

4. Conclusions

258

The total mass concentrations of the surface water samples collected along Nankan

259 River decreased from upstream to downstream, but the MI values followed the opposite

260 pattern. To evaluate the differences in source contributions determined using the total

261 mass concentration and MI, the EV-CMB was employed. The modeling results revealed

262 that SCM and BPCB were the main pollution sources upstream and downstream,

263 respectively. In addition to SCM and $\mathrm{BPCB}$, domestic wastewater was one of the main

264 sources of water pollution in the metropolitan area.

265 In this technical report, we demonstrated the feasibility of applying the EV-CMB

266 model in the strategic investigation of river pollution. Establishing a comprehensive

267 source profile database is recommended for effective source identification and 268 apportionment.

269

270 Acknowledgments

271 We thank our co-workers from the National Institute of Environmental Analysis,

272 Environmental Protection Administration of Taiwan who greatly assisted this project. 
273 We would also like to express our sincere gratitude to the samplers and analysts for

274 their hard work.

275

276 Statements \& Declarations

277 Funding

278 This work was funded by the National Institute of Environmental Analysis,

279 Environmental Protection Administration of Taiwan (EPA-106-S3E4-02-05 and

280 EPA154108017).

281 Competing Interests

282 The authors declare that they have no competing interests.

283 Author Contributions

284 Conceptualization: Pei-Yuan Hsieh, Chi-Chang Ho, Gen-Shuh Wang, Yu-Man Shang,

285 and Chang-Fu Wu; Methodology: Pei-Yuan Hsieh and Chi-Chang Ho; Software: Pei-

286 Yuan Hsieh; Visualization: Pei-Yuan Hsieh; Formal Analysis: Pei-Yuan Hsieh;

287 Investigation: Pei-Yuan Hsieh, Chi-Chang Ho, Yuan-Jeng Hsu, and Yu-Man Shang;

288 Data curation: Yuan-Jeng Hsu and Di-Wen Wang; Resources: Yuan-Jeng Hsu and Di-

289 Wen Wang; Writing - original draft: Pei-Yuan and Chi-Chang Ho; Writing - review \&

290 editing: Chang-Fu Wu; Supervision: Gen-Shuh Wang, Yuan-Jeng Hsu, and Chang-Fu

$291 \mathrm{Wu}$; Project administration: Gen-Shuh Wang, Yuan-Jeng Hsu, and Chang-Fu Wu. 


\section{Data Availability}

293 Restrictions apply to the availability of these data, which were used under license for 294 this study. The data are available from the corresponding author with the permission of 295 Environmental Analysis Laboratory, Environmental Protection Administration, Taiwan.

296

297

\section{References}

298

299

300

301

302

303

304

305

Abdo, M. and El-Nasharty, S., 2010. Physico-chemical evaluations and trace metals distribution in water-surficial sediment of Ismailia Canal, Egypt. Nature and Science 8(5), 198-206.

Akbal, F., Gürel, L., Bahadır, T., Güler, İ., Bakan, G. and Büyükgüngör, H., 2011. Multivariate Statistical Techniques for the Assessment of Surface Water Quality at the Mid-Black Sea Coast of Turkey. Water, Air, \& Soil Pollution 216(1), 21-37.

Antony Chen, L.W., Watson, J.G., Chow, J.C., DuBois, D.W. and Herschberger, L., 2010. Chemical mass balance source apportionment for combined PM2.5 measurements from U.S. non-urban and urban long-term networks. Atmospheric Environment 44(38), 4908-4918.

Chow, J., Watson, J., Lowenthal, D., Chen, L., Zielinska, B., Mazzoleni, L. and Magliano, K., 2007. Evaluation of organic markers for chemical mass balance 
source apportionment at the Fresno Supersite. Atmospheric Chemistry and Physics 7(7), 1741-1754.

313 Fishar, M. and Ali, M., 2005. Accumulation of trace metals in some benthic invertebrate and fish species revelant to their concentration in water and 289-301.

Goher, M.E., Hassan, A.M., Abdel-Moniem, I.A., Fahmy, A.H. and El-sayed, S.M., 2014. Evaluation of surface water quality and heavy metal indices of Ismailia $225-233$.

Ismail, A., Toriman, M.E., Juahir, H., Zain, S.M., Habir, N.L.A., Retnam, A., Canal, Nile River, Egypt. The Egyptian Journal of Aquatic Research 40(3), Kamaruddin, M.K.A., Umar, R. and Azid, A., 2016. Spatial assessment and source identification of heavy metals pollution in surface water using several chemometric techniques. Marine Pollution Bulletin 106(1), 292-300.

Jiang, J., Khan, A.U., Shi, B., Tang, S. and Khan, J., 2019. Application of positive matrix factorization to identify potential sources of water quality deterioration

328 Kowalkowski, T., Zbytniewski, R., Szpejna, J. and Buszewski, B., 2006. Application of chemometrics in river water classification. Water research 40(4), 744-752. 
Kumar, V., Parihar, R.D., Sharma, A., Bakshi, P., Sidhu, G.P.S., Bali, A.S., Karaouzas, I., Bhardwaj, R., Thukral, A.K. and Gyasi-Agyei, Y., 2019. Global evaluation of heavy metal content in surface water bodies: A meta-analysis using heavy metal pollution indices and multivariate statistical analyses. Chemosphere $236,124364$.

Li, H., Hopke, P.K., Liu, X., Du, X. and Li, F., 2015. Application of positive matrix factorization to source apportionment of surface water quality of the Daliao River basin, northeast China. Environ Monit Assess 187(3), 80.

Palma, P., Alvarenga, P., Palma, V.L., Fernandes, R.M., Soares, A.M.V.M. and Barbosa, I.R., 2010. Assessment of anthropogenic sources of water pollution using multivariate statistical techniques: a case study of the Alqueva's reservoir, Portugal. Environmental Monitoring and Assessment 165(1), 539552.

Polissar, A.V., Hopke, P.K., Paatero, P., Malm, W.C. and Sisler, J.F., 1998. Atmospheric aerosol over Alaska: 2. Elemental composition and sources. Journal of Geophysical Research: Atmospheres 103(D15), 19045-19057.

Shil, S. and Singh, U.K., 2019. Health risk assessment and spatial variations of dissolved heavy metals and metalloids in a tropical river basin system. Ecological Indicators 106, 105455. 
Simeonov, V., Stratis, J.A., Samara, C., Zachariadis, G., Voutsa, D., Anthemidis, A., Sofoniou, M. and Kouimtzis, T., 2003. Assessment of the surface water quality in Northern Greece. Water research 37(17), 4119-4124.

Soonthornnonda, P. and Christensen, E.R., 2008. Source apportionment of pollutants and flows of combined sewer wastewater. Water Research 42(8-9), 1989-1998.

Tamasi, G. and Cini, R., 2004. Heavy metals in drinking waters from Mount Amiata (Tuscany, Italy). Possible risks from arsenic for public health in the Province of Siena. Science of the Total Environment 327(1-3), 41-51.

TEPA 2004 The General Provisions of River, Lake, Reservoir Water Quality Sampling (NIEA W104), Environmental Protection Administration, Executive Yuan, R.O.C. (Taiwan).

TEPA 2019 Sampling methods for industrial effluent (NIEA W109), Environmental Protection Administration, Executive Yuan, R.O.C. (Taiwan).

Van der Voet, G.B., Todorov, T.I., Centeno, J.A., Jonas, W., Ives, J. and Mullick, F.G., 2007. Metals and health: a clinical toxicological perspective on tungsten and review of the literature. Military medicine 172(9), 1002-1005.

Vu, C.T., 2017. Contamination, ecological risk and source apportionment of heavy metals in sediments and water of a contaminated river in Taiwan. Ecological indicators v. 82, pp. 11-42-2017 v.2082. 
368 Wasel, O. and Freeman, J.L., 2018. Comparative assessment of tungsten toxicity in the absence or presence of other metals. Toxics $6(4), 66$.

370 Watson, J.G., Cooper, J.A. and Huntzicker, J.J., 1984. The effective variance weighting for least squares calculations applied to the mass balance receptor model. Atmospheric Environment (1967) 18(7), 1347-1355.

373 Witten, M.L., Sheppard, P.R. and Witten, B.L., 2012. Tungsten toxicity. Chemicobiological interactions 196(3), 87-88.

375 Zanotti, C., Rotiroti, M., Fumagalli, L., Stefania, G., Canonaco, F., Stefenelli, G., Prévôt, A., Leoni, B. and Bonomi, T., 2019. Groundwater and surface water quality characterization through positive matrix factorization combined with GIS approach. Water Research 159, 122-134.

379 Zhou, F., Huang, G.H., Guo, H., Zhang, W. and Hao, Z., 2007. Spatio-temporal patterns and source apportionment of coastal water pollution in eastern Hong Kong. Water research 41(15), 3429-3439. 
384 Water quality standards of TEPA for heavy metal content in the surface water

\begin{tabular}{llllllllllll}
\hline Element & $\mathrm{Ag}$ & $\mathrm{As}$ & $\mathrm{Cd}$ & $\mathrm{Cr}^{6+}$ & $\mathrm{Cu}$ & $\mathrm{Hg}$ & $\mathrm{Mn}$ & $\mathrm{Ni}$ & $\mathrm{Pb}$ & $\mathrm{Se}$ & $\mathrm{Zn}$ \\
\hline $\mathrm{MAC}$ & & & & & & & & & & & \\
$\left(\mu \mathrm{g} \mathrm{L}^{-1}\right)$ & 50 & 50 & 5 & 50 & 30 & 1 & 50 & 100 & 10 & 10 & 500 \\
\hline
\end{tabular}

385 
(a)

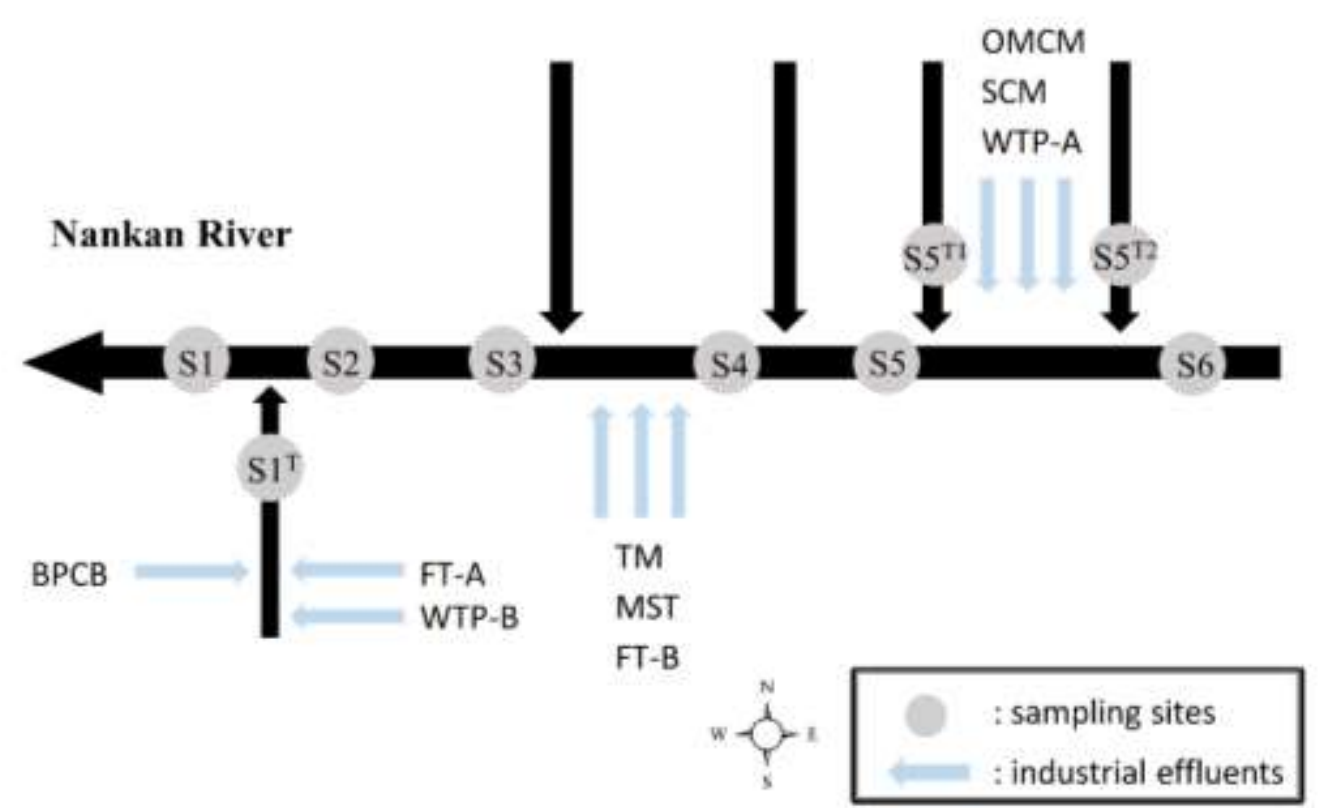

(b)

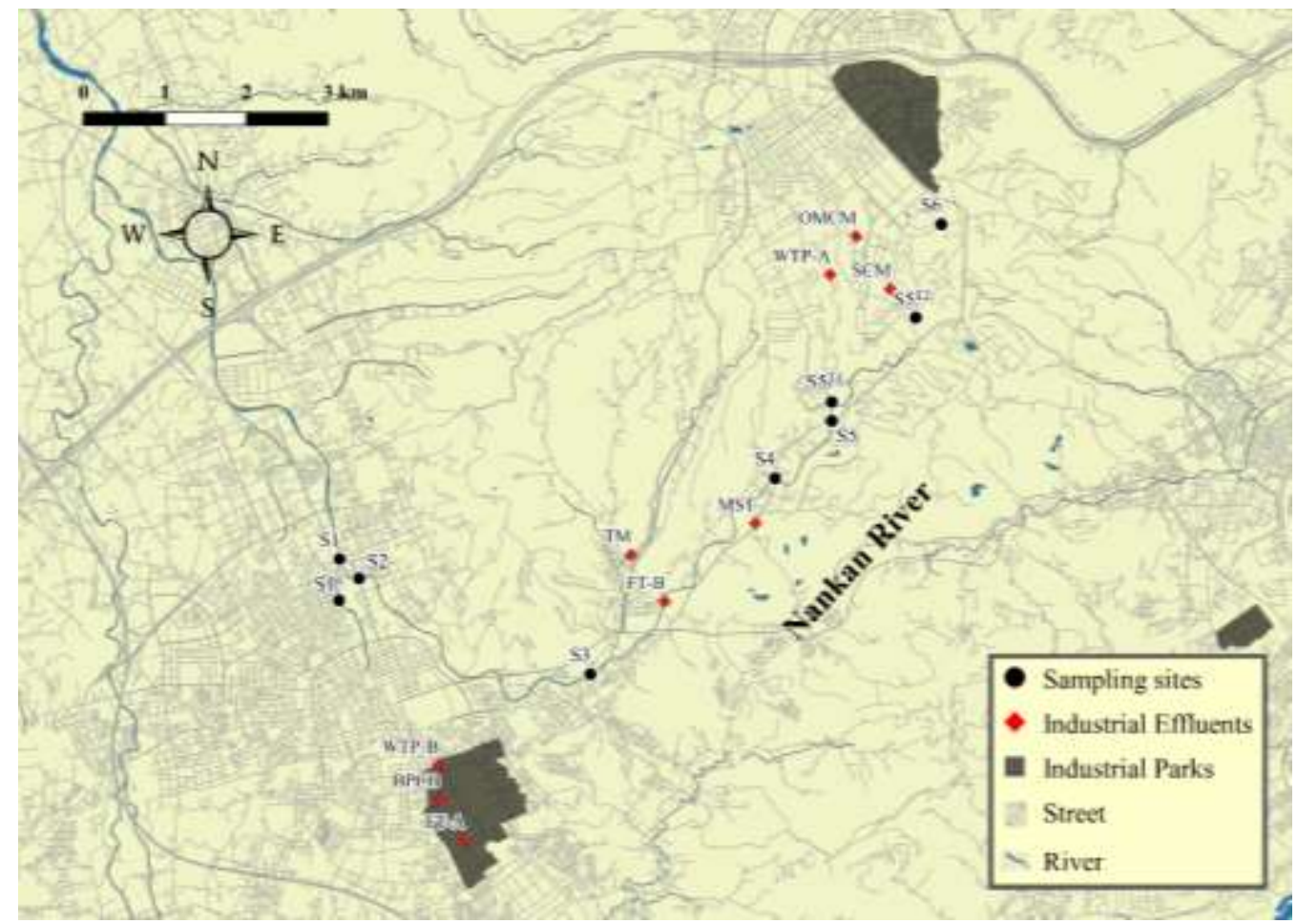

Fig. 1. Locations of the sampling sites and industrial effluents in Nankan River. (a) A

387 fishbone diagram of the locations of the sampling sites and industrial effluents in

388 Nankan River; (b) research area map.

389 Note. $\mathrm{WTP}=$ wastewater treatment plants; $\mathrm{OMCM}=$ optoelectronic materials and 
390 components manufacturing; $\mathrm{SCM}=$ semi-conductors manufacturing; $\mathrm{FT}=$ finishing

391 of textiles; $\mathrm{BPCB}=$ bare printed circuit boards; $\mathrm{TM}=$ textiles mills; $\mathrm{MST}=$ metal

392 surface treatment. 

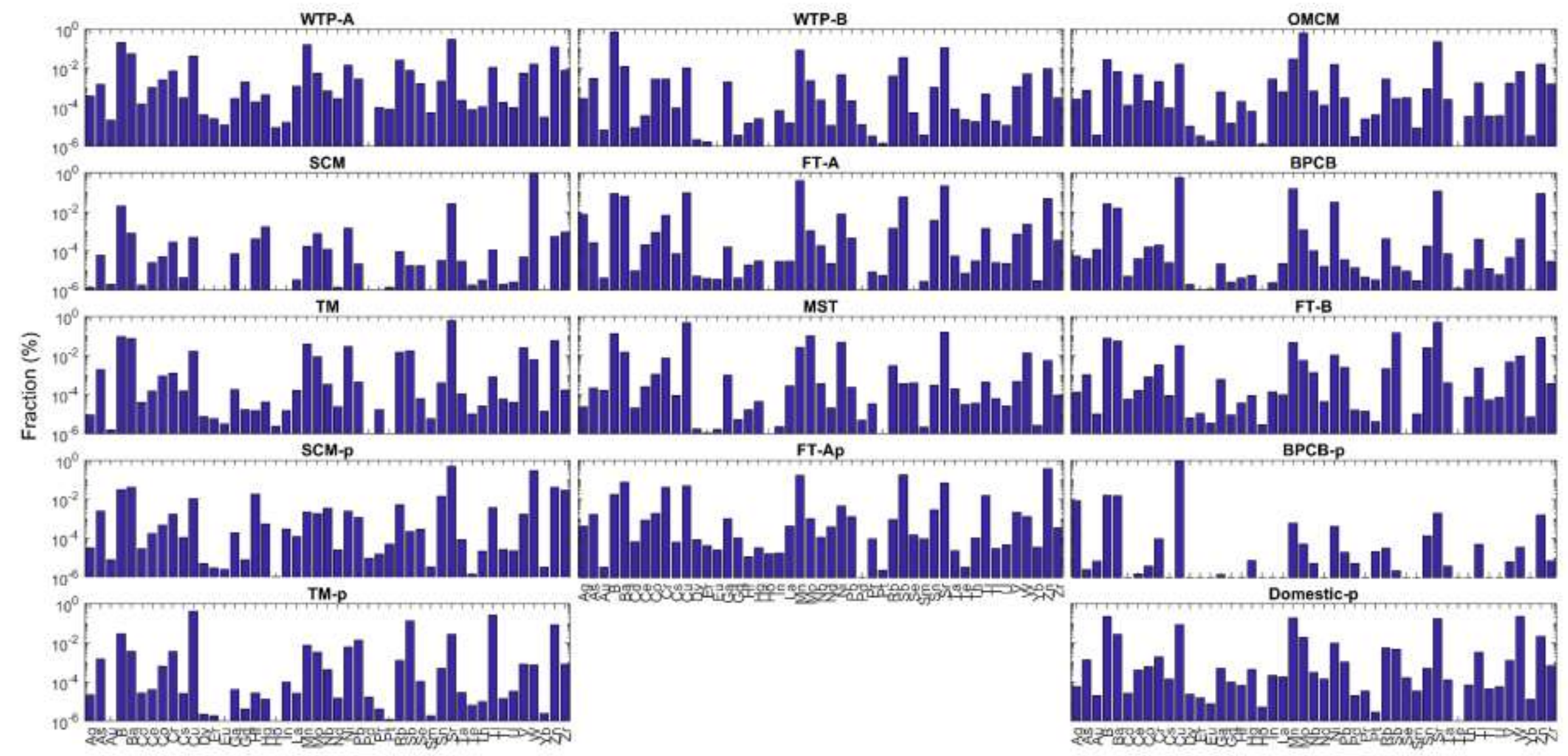

Fig. 2. Source profiles of industrial effluents, untreated unit discharges and untreated domestic wastewater. Only 47 species used in EV-CMB are 


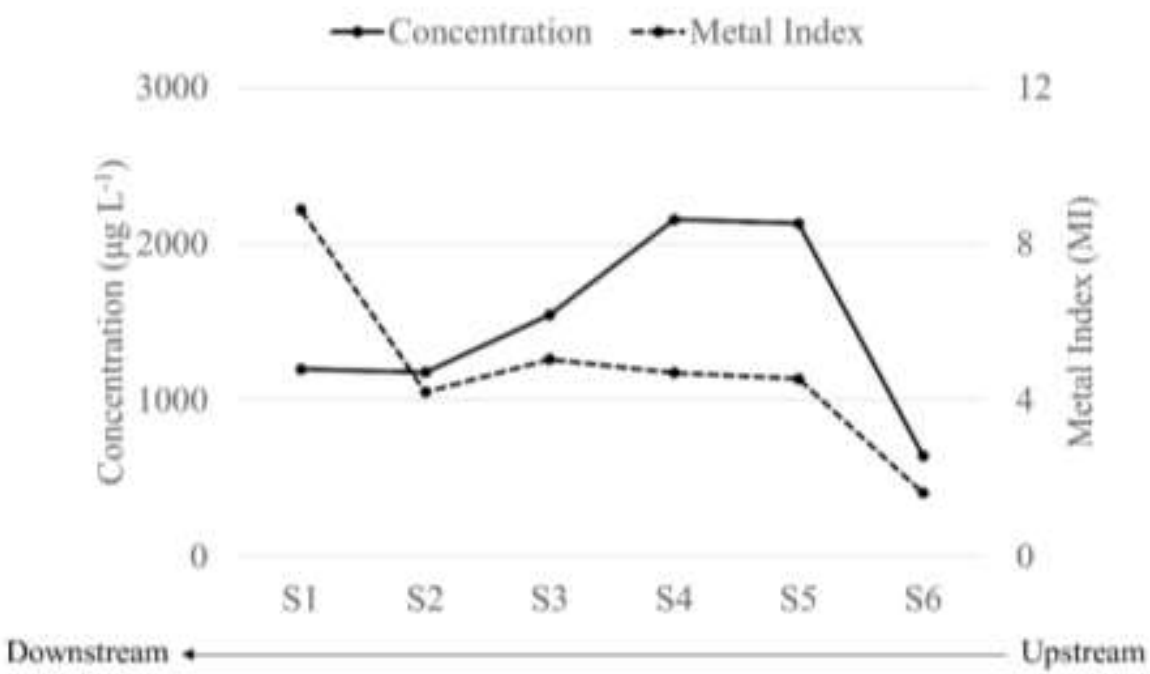

Fig. 3. Spatial variation in total mass concentration and metal index (MI) at sampling sites along Nankan River. S6 is the background river water. 


\begin{tabular}{|c|c|c|c|c|c|c|c|c|c|}
\hline $\mathrm{Ag}$ & 0.00 & 0.00 & 0.00 & 0.00 & 0.00 & 0.00 & 0.00 & 0.00 & 0.00 \\
\hline As & 0.03 & 0.02 & 0.05 & 0.06 & 0.07 & 0.08 & 0.01 & 0.01 & 0.03 \\
\hline $\mathrm{Cd}$ & 0.01 & 0.01 & 0.01 & 0.01 & 0.01 & 0.01 & 0.01 & 0.01 & 0.01 \\
\hline $\mathrm{Cr}$ & 0.05 & 0.09 & 0.06 & 0.07 & 0.07 & 0.05 & 0.07 & 0.05 & 0.05 \\
\hline $\mathrm{Cu}$ & 3.45 & 7.82 & 0.67 & 0.88 & 0.42 & 0.46 & 0.38 & 0.19 & 0.26 \\
\hline $\mathrm{Hg}$ & 0.52 & 0.05 & 0.99 & 1.54 & 2.53 & 2.42 & 0.08 & 5.24 & 0.11 \\
\hline $\mathrm{Mn}$ & 4.51 & 5.97 & 2.07 & 2.13 & 1.36 & 1.28 & 1.54 & 0.28 & 0.90 \\
\hline $\mathrm{Ni}$ & 0.12 & 0.17 & 0.07 & 0.08 & 0.06 & 0.07 & 0.07 & 0.07 & 0.03 \\
\hline $\mathrm{Pb}$ & 0.13 & 0.08 & 0.20 & 0.19 & 0.09 & 0.10 & 0.10 & 0.03 & 0.10 \\
\hline $\mathrm{Se}$ & 0.02 & 0.01 & 0.03 & 0.03 & 0.04 & 0.04 & 0.05 & 0.03 & 0.02 \\
\hline $\mathrm{Zn}$ & 0.05 & 0.05 & 0.06 & 0.06 & 0.04 & 0.05 & 0.07 & 0.02 & 0.10 \\
\hline & S1 & $\begin{array}{c}\mathrm{SI}^{\mathrm{T}} \\
\boldsymbol{\Lambda}\end{array}$ & S2 & S3 & S4 & S5 & $\begin{array}{l}\mathrm{S}^{\mathrm{TI}} \\
\Delta\end{array}$ & $\begin{array}{l}\mathrm{S}^{\mathrm{T} 2} \\
\Delta\end{array}$ & S6 \\
\hline
\end{tabular}

Fig. 4. Heatmap of 11 unit MIs along Nankan River. Black triangles indicate sites near mouths of tributaries. 


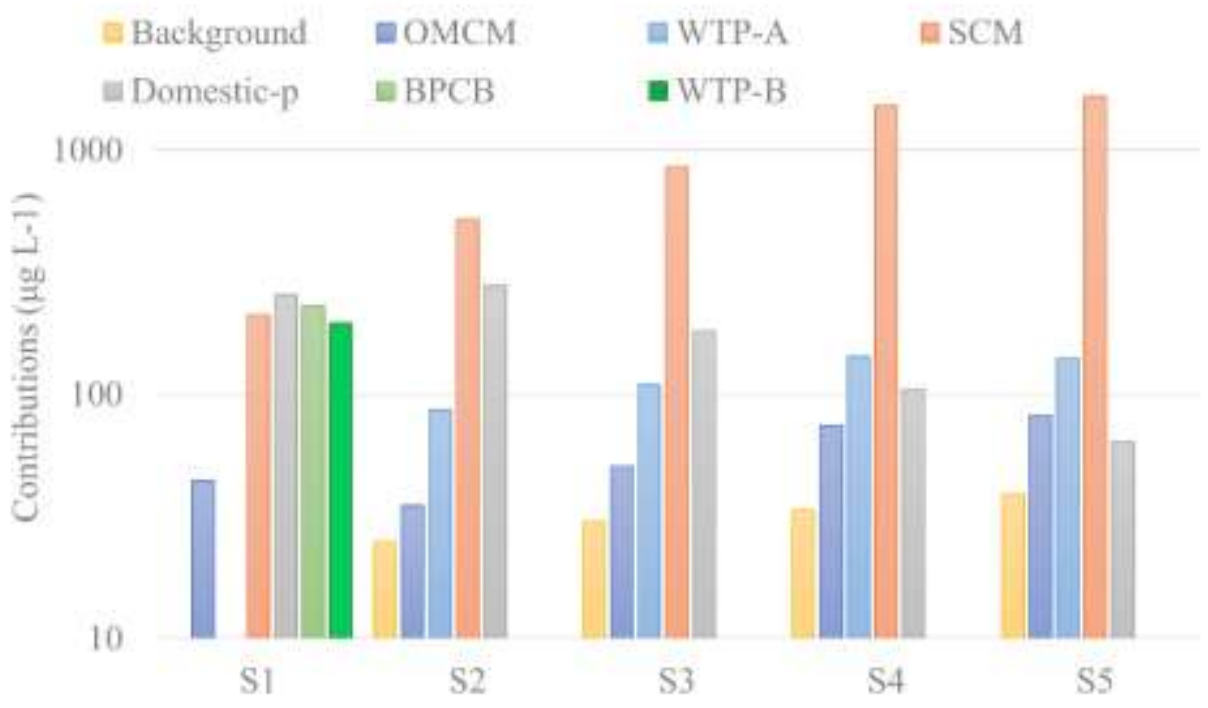

Fig. 5 Concentration contributions of each pollution source at five receptor sites. 


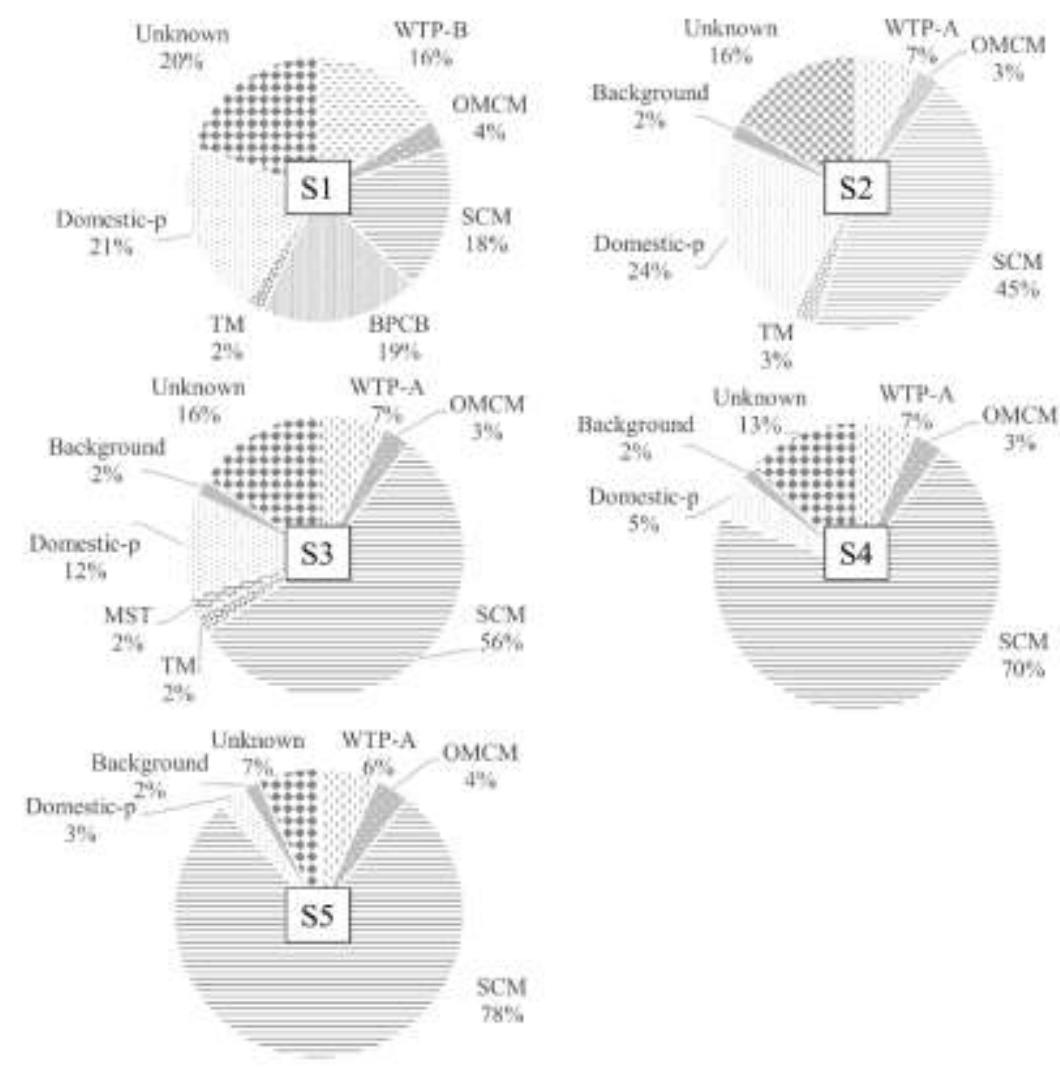

Fig. 6. Proportions of concentration contributions from industrial effluents at five receptor sites. 


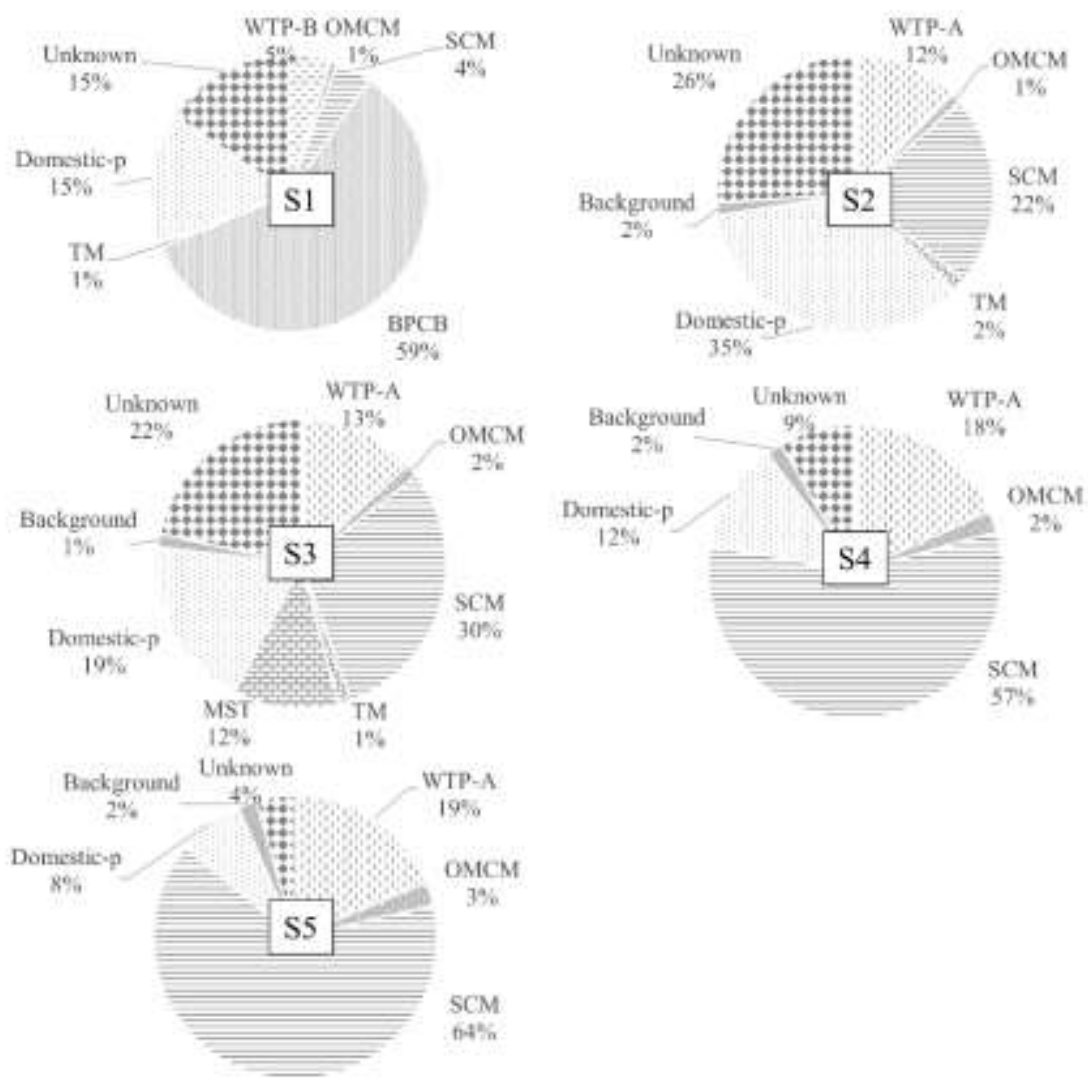

Fig. 7. Proportions of MI contributions from industrial effluents at five receptor sites. 


\section{Supplementary Files}

This is a list of supplementary files associated with this preprint. Click to download.

- supplmCMBnankan.docx 